\title{
Testicular Sertoli Cell Tumor
}

National Cancer Institute

\section{Source}

National Cancer Institute. Testicular Sertoli Cell Tumor. NCI Thesaurus. Code C4672.

A sex cord-stromal tumor that arises from the testis and is characterized by the presence of neoplastic cells with features of Sertoli cells. It usually presents as a slow growing testicular mass. The vast majority of cases follow a benign clinical course. 